\title{
Wybrane zagadnienia dobrych praktyk współpracy środowiska architektów z władzami samorządowymi oraz uczelniami wyższymi
}

\section{Selected issues of good practice in case of cooperation between architect's societies and local authorities or higher education}

\section{Streszczenie}

Niniejszy artykuł prezentuje wybór dobrych praktyk dotyczących współpracy środowiska architektów z władzami samorządowymi oraz uczelniami wyższymi. Wyselekcjonowane przykłady prezentują rozwiązania wymagające popularyzacji w celu zbudowania atrakcyjnego rynku dla inwestycji prezentujących najwyższe walory jakościowe czy estetyczne w oparciu o publiczne inwestycje w sektorze budowlanym. Środowisko architektów jest grupą najmocniej zaangażowaną w misję tworzenia wysokiej klasy architektury, odpowiadającej najnowszym trendom.

Słowa kluczowe: modele współpracy, uczelnia wyższa, samorząd, środowisko architektów, biznes

\section{Abstract}

This article presents a selection of good practices regarding the cooperation of the architects societies with local authorities and universities. Selected examples present solutions that need to be popularized in order to build an attractive market for investments representing the highest qualities or aesthetics based on public investment in the construction sector. The architects' is the group most involved in the mission of creating high-end architecture that responds to the latest trends.

Keywords: models of cooperation, higer education, local authoryties, architects', business 


\section{WSTĘP}

Wiele spośród rzeczy, które możesz policzyć, nie liczq się. Wiele z tych, których policzyć nie można, naprawdę się liczq.

Albert Einstein

Zawsze trzeba działać. Źle czy dobrze, okaże się później. Żałuje się wyłącznie bezczynności, niezdecydowania, wahania. Czynów i decyzji, choć niekiedy przynoszq smutek i żal, nie żałuje się.

Andrzej Sapkowski

Społeczeństwo to zbiór ludzi o różnym wykształceniu, zainteresowaniach czy statusie, ale powiązanych ze sobą relacjami, w wyniku czego współpraca jest istotna i nieodzowna zarówno w życiu codziennym, jak i przy próbie budowania czegoś lub jakiejś wartości. Dzięki wielu kooperacjom w społecznościach może być wspierany jakikolwiek rozwój. Współpraca między szeroko rozumianym samorządem oraz biznesem jest we współczesnej demokracji bardzo istotna. Ponadto do wspomagania, kierowania i przewidywania procesów społeczno-gospodarczych potrzebnych jest dzisiaj wielu specjalistów i wiele punktów widzenia. Architektura jako katalizator lub skutek takich działań może również być utożsamiana ze statusem lub jakością środowiska czy otoczenia.

Architekci z racji wieloaspektowego i ustawicznego wykształcenia oraz jako osoby wykonujące zawód zaufania publicznego należą do grupy osób świadomie i odpowiedzialnie podejmujących zagadnienia ładu oraz harmonii w środowisku zurbanizowanym i nie tylko, jak również zrównoważonego rozwoju, a także kształtowania inteligentnych struktur miejskich. Niniejszy artykuł jest próbą opisania modeli współpracy architektów, zrzeszonych w organizacjach zawodowych lub stowarzyszeniach oraz strukturach samorządowych (miejskich i wojewódzkich). Takie działania określić można jako zbiór dobrych praktyk kształtujących świadomość pojęcia jakości przestrzeni życia. Przez kooperację samorządu, biznesu oraz twórczości architektonicznej, wywodzącej się często z myśli akademickiej reprezentowanej przez idee projektowe, powstają wspaniałe realizacje przestrzeni i architektury, w której żyjemy.

Poniższe przykłady opisują warte dłuższego zastanowienia i większej uwagi działania z ostatnich lat z udziałem m.in. Izby Architektów oraz Stowarzyszenia Architektów Polskich SARP, przedstawiające dobre praktyki prowadzące do kształtowania jakości w urbanistyce i architekturze, co ma jednocześnie wpływ na pozostałe, także ekonomiczne, dziedziny i aspekty funkcjonowania miast oraz regionów. 


\section{SARP}

Stowarzyszenie Architektów Polskich to organizacja zrzeszająca dobrowolnie wstępujących do niej architektów. Historia działalności stowarzyszeniowej architektów polskich liczy już 140 lat. Na początku była to inicjatywa budowniczych i inżynierów tworzących Krakowskie Towarzystwo Techniczne (1877)1. W 1934 roku powstało Stowarzyszenie Architektów Rzeczpospolitej Polskiej SARP. W 1952 roku na VI Walnym Zjeździe Delegatów SARP zmieniono nazwę na Stowarzyszenie Architektów Polskich, zachowując tradycyjny skrót SARP. Taką właśnie nazwę Stowarzyszenie nosi do dnia dzisiejszego. Do SARP-u należy obecnie ponad 5000 architektów². Organizacja ta w przeciwieństwie do Izby Architektów nie nadaje uprawnień do wykonywania zawodu, ale ocenia twórczość, nagradzając osoby o wybitnych zasługach lub osiągnięciach. Obecnie Stowarzyszenie liczy 25 oddziałów z własną hierarchią oraz zespoły eksperckie.

\subsection{KONKURSY ARCHITEKTONICZNE}

Jednym z wielu przykładów, kiedy dochodzi do współpracy jednostki samorządowej (przedstawiciela miasta lub województwa), jest zlecenie organizacji konkursu architektonicznego jedno- lub wieloetapowego według specyfikacji zamawiającego. „Podstawowym celem działania Stowarzyszenia Architektów Polskich jest wysoka jakość architektury i przestrzeni. Cel ten realizowany jest przede wszystkim przez organizację konkursów architektonicznych, które uważamy za najlepszy sposób wyboru projektantów, zarówno z punktu widzenia korzyści inwestora, jak i projektanta. Procedura konkursowa pozwala na otrzymanie wielu rozwiązań projektowych i analizę wariantów. Wybór najlepszego projektu opiera się na wartości merytorycznej i estetycznej projektu" ${ }^{3}$. SARP w swojej strukturze posiada sędziów konkursowych, wyznacza sekretarza, pisze warunki, jednym słowem organizuje taki konkurs. Należy tu zaznaczyć, że tylko dwie organizacje (SARP w połączeniu z Izbą Architektów) dbają o interesy wszystkich architektów. Stowarzyszenie konstruuje warunki konkursowe tak, aby przede wszystkim zostały uszanowane prawa autorskie. Jak pokazuje nam krakowski rynek, zdarzały się konkursy, w których organizacja słusznie nie rekomendowała udziału z uwagi na nieposzanowanie praw autorów i które nie odbiły się pozytywnym echem w świecie architektury. Krakowski oddział SARP może pochwalić się wieloma dobrze zorganizowanymi konkursami na zlecenie Urzędu Miasta Krakowa czy marszałka województwa małopolskiego, ZIKiT-u itd.

W dniach 27-28 czerwca 2014 roku w Warszawie odbyło się Forum Konkursów Architektonicznych: „Konkurs jako instrument kreowania ładu przestrzennego, wysokiej jakości budynków i przestrzeni publicznych". Celem konferencji było omówienie założeń i tez dotyczących doświadczenia, standardów, regulacji i praktyk z zakresu kultury i kształtowania ładu w przestrzeni. Wydawnictwo pokonferencyjne zawiera przykłady wyróżnionych i dobrze 
zorganizowanych konkursów, w wyniku których powstały znaczące dla kraju realizacje, a także wypowiedzi osób piastujących wysokie i odpowiedzialne stanowiska w państwie. Pani Elżbieta Bieńkowska - ówczesny wiceprezes Rady Ministrów i Minister Infrastruktury i Rozwoju objęła patronatem tę konferencję, co świadczy o jej wysokiej randze. „Jako swoisty obowiązek względem mieszkańców i ducha miasta postrzegać należy objęcie trybem konkursowym kluczowych inwestycji publicznych w miastach, w tym przestrzeni ogólnodostępnych. To samo dotyczy dużych założeń urbanistycznych. Warto też myśleć o wykorzystaniu procedur konkursowych w wyłanianiu najlepszych rozwiązań dla miast także w innych niż architektura i urbanistyka dziedzinach. Procesy te powinny odbywać się przy współudziale mieszkańców oraz aktywnej roli władz miejskich. Pojęcie takie w naturalny sposób wpisuje się w ideę partycypacji, tworząc kulturę dialogu i dyskusji poprzedzających kluczowe rozstrzygnięcia przestrzenne, funkcjonalne i estetyczne" ${ }^{\prime 4}$. Tezy konferencji odnosiły się do czterech pojęć:

- „Konkurs jest najlepszym narzędziem dla wyboru optymalnego rozwiązania i kompetentnego projektanta dla kreowania zabudowy i przestrzeni publicznych.

- Jakość powinna być nadrzędnym kryterium w Zamówieniach Publicznych na prace projektowe z zakresu architektury i urbanistyki.

- Kryterium najniższej ceny w procedurze Zamówień Publicznych jest podstawowym zagrożeniem dla jakości projektowania i przyszłej realizacji, dla użytkownika i społeczeństwa oraz powodem obniżania standardów wykonywania zawodu architekta.

- Rekomendacja dla konkursów w procedurach Zamówień Publicznych na projektowanie architektoniczne i urbanistyczne w inwestycjach publicznych"5.

Ponadto poruszone zostały zagadnienia znaczenia ładu przestrzennego jako nieodłącznego atrybutu rozwoju zrównoważonego, rozumianego w ujęciu dla warunków życia obywateli i funkcjonowania oraz szans rozwojowych dla gospodarki, które stać się powinny jednym z najważniejszych zadań dla władz publicznych, legitymując jednocześnie architekturę i urbanistykę jako sztukę kształtowania przestrzeni. Opracowane przykłady dobrych praktyk dotyczą modelowych przykładów architektury budynków użyteczności publicznej i przestrzeni publicznych z terenu całej Polski, których powstanie zostało poprzedzone omawianą procedurą konkursową. Ponadto opracowanie zawiera rozdziały omawiające takie aspekty jak:

- Ustawa Prawo zamówień publicznych z dnia 29 stycznia 2004 r.,

- zasady organizacji konkursów architektonicznych, architektoniczno-urbanistycznych i urbanistycznych, opracowane przez SARP - kodeks konkursowy SARP,

- wytyczne organizacji i przeprowadzania konkursów architektonicznych architektoniczno-urbanistycznych i urbanistycznych, opracowane przez SARP,

- kodeks konkursów architektonicznych, architektoniczno-urbanistycznych i urbanistycznych, opracowane przez SARP,

- przepisy dotyczące konkursów w nowej dyrektywie 2014/24/UE z 26 lutego 2014 r.,

- standardowe warunki UNESCO dla międzynarodowych konkursów architektonicznych i urbanistycznych. 
Publikacja ta wydaje się być kompleksowym rozwiązaniem dla organów pragnących zaznajomić się z procedurą konkursową dotyczącą realizacji publicznych. Według danych z 2013 roku na 140000 przetargów w sektorze projektowania zorganizowanych w Polsce przeprowadzono tylko 138 konkursów architektonicznych, co wydaję się być dość niepokojącą statystyką, wynoszącą zaledwie 0,1\%.

Patrząc na sytuację na rynku krakowskim, wygląda to nieco bardziej optymistycznie. W strukturach władzy miejskiej (urzędach) zasiadają architekci z wykształcenia, a nawet członkowie SARP-u czy Małopolskiej Izby Architektów, co może wpływać na większą świadomość i powszechność procedury konkursowej niż podają statystyki.

\subsection{MIĘDZYNARODOWE BIENNALE ARCHITEKTURY}

Inny model współpracy pomiędzy środowiskiem architektów a władzą samorządową dotyczy wydarzenia, jakim jest Międzynarodowe Biennale Architektury Kraków, które ostatnio odbyło się w 2015 roku, a po raz kolejny w październiku 2017 roku. Organizatorami wydarzenia są: Prezydent Miasta Krakowa Jacek Majchrowski (Kraków - Miasto Gospodarz Biennale) oraz Stowarzyszenie Architektów Polskich (SARP) oddział Kraków. Partnerem jest Centrum Kongresowe ICE Kraków, a honorowym patronatem objęły biennale takie instytucje i osoby je reprezentujące jak: Piotr Gliński - Minister Kultury i Dziedzictwa Narodowego, Andrzej Adamczyk - Minister Infrastruktury i Budownictwa, Piotr Ćwik Wojewoda Małopolski, Jacek Krupa - Marszałek Województwa Małopolskiego, Małopolska Okręgowa Izba Architektów RP, Muzeum Sztuki i Techniki Japońskiej Manggha, Muzeum Historyczne Miasta Krakowa oraz Związek Polskich Artystów Plastyków Okręg Kraków. Świadczy to o ogromnym rozmachu imprezy kulturalnej, promującej przez konkursy, wystawy, wykłady najlepsze przykłady i praktyki w dziedzinie architektury i urbanistyki. Jak można przeczytać na stronie internetowej wydarzenia: „MBA jest imprezą cykliczną, odbywającą się w Krakowie od 1985 roku. Każda kolejna edycja stanowiła niepowtarzalne forum wymiany pomysłów i doświadczeń dla architektów z całego świata. Towarzyszące temu konkursy, wystawy, prezentacje i wykłady stanowią unikalną w tej części Europy atrakcję dla wszystkich związanych z architekturą". Wiodący teoretyk rozprawiający o humanizacji miast, profesor Jan Gehl, jest przekonany, że poprawa jakości naszego życia w miastach wynika ze zmiany wyglądu przestrzeni publicznych, gdzie „spotykają się ludzie, by wymieniać się pomysłami, handlować lub po prostu odpoczywać. Strefa publiczna miasta - ulice, place i parki - jest jednocześnie sceną i katalizatorem tych aktywności"6. Obustronna współpraca pomiędzy SARP-em a miastem wpływa na ich wzajemną reklamę w świecie, ściąga wybitne autorytety, podnosi świadomość architektoniczną i estetyczną w społeczeństwie. Jest to również wspaniała okazja do zaprezentowania często wizjonerskich i dla wielu dotąd wystarczająco niezgłębionych zagadnień oraz problemów czy rozwiązań architektoniczno-urbanistycznych. 


\subsection{WSPÓŁPRACA Z UCZELNIAMI WYŻSZYMI}

Warto wspomnieć o formach współpracy Stowarzyszenia Architektów Polskich z uczelniami wyższymi na terenie Krakowa. Jedną z nich jest Stypendium Twórcze SARP Kraków im. prof. Bohdana Lisowskiego, które przyznawane jest wybitnie uzdolnionym studentom wydziałów architektury krakowskich uczelni wyższych, którzy ukończyli pomyślnie III rok studiów, uzyskali licencjat oraz rozpoczynają studia magisterskie. Celem dofinansowania $w$ formie pieniężnej w formie 9 rat jest umożliwienie doskonalenia umiejętności i zdolności twórczych, a także podjęcie dodatkowej edukacji. Laureaci otrzymują też możliwość odbycia 3-miesięcznej płatnej praktyki zawodowej w biurze architektonicznym oraz są zobowiązani do zdania sprawozdania z dokonań twórczych w czasie korzystania ze stypendium.

Innym sposobem nagradzania studenckiej twórczości jest przyznawanie dorocznej Nagrody Stowarzyszenia Architektów Polskich SARP im. Zbyszka Zawistowskiego-Dyplom Roku 2017 oraz Krakowskiej Nagrody SARP za Najlepszy Dyplom Roku na wydziałach architektury w Krakowie. „Do konkursu mogą być zgłaszane prace dyplomowe, magisterskie, wykonane na uczelni w ramach kształcenia skutkującego nadaniem dyplomu architekta, w roku akademickim poprzedzającym rok przeprowadzenia konkursu, które uzyskały pozytywną opinię Komisji Dyplomowej danego Wydziału Architektury"7.

\section{IZBA ARCHITEKTÓW}

Również warte przedstawienia są działania innej organizacji zawodowej. Izba Architektów Rzeczypospolitej Polskiej (IARP) to jednostka organizacyjna samorządu zawodowego, działającego na podstawie ustawy z dnia 15 grudnia 2000 r. o samorządach zawodowych architektów oraz inżynierów budownictwa. Nadrzędnym celem statutowym IARP jest „ochrona przestrzeni i architektury jako dobra publicznego" przez sprawowanie nadzoru nad należytym wykonywaniem zawodu oraz przestrzeganiem zasad etyki zawodowej przez wszystkich członków IARP. Takie działania realizowane są przez struktury samorządu oraz przepisy i ustawy gwarantujące dostęp do zawodu, co ma na celu zagwarantować najwyższą jakość projektów budynków z uwzględnieniem potrzeb użytkownika końcowego obiektu oraz działek sąsiednich, a także często interes inwestora. Architekci zobowiązani są zachować wartości kulturowe i dbać o ład przestrzenny jako dobro publiczne. Na terenie województwa kompetentną jest Małopolska Okręgowa Izba Architektów, zarządzana przez organ rady z przewodniczącym i strukturami towarzyszącymi. 


\subsection{DOM DLA RODZINY}

Konferencja „Dom dla rodziny”, która odbyła się w Krynicy w dniach 21-22 października 2016 roku jest przejawem troski MPOIA o ład przestrzenny i jakość architektury nie tylko w dziedzinie budownictwa mieszkaniowego. Zorganizowana forma dyskusji z udziałem władz samorządowych, a także przedstawicieli resortów ministerialnych (jak np. podsekretarz stanu ds. budownictwa w Ministerstwie Infrastruktury i budownictwa - Tomasz Żuchowski, oraz zespół prawników, autorów nowych ustaw, a także kierownicy urzędów i administracji publicznej) skutkowała wymianą cennych doświadczeń i opracowaniem wielu kompromisów, które bez obustronnego dialogu nie byłyby możliwe. Ostatnia edycja konferencji zdominowana została jednak dyskusjami wokół nowego Kodeksu Urbanistyczno-Budowlanego. Czynnie wypowiedziało się wiele autorytetów, nakreślając wizje planowanych zmian prawnych oraz ich skutków. Działa związane ze zmianą istniejącego Prawa Budowlanego w swoim założeniu mają na celu stworzenie lepszego modelu prowadzenia inwestycji w oparciu o budownictwo w zakresie urbanistyki i architektury. Stworzenie bardziej bezpiecznych i przejrzystych warunków, zarówno w celu szybszego planowania, jak i realizacji kosztochłonnych zamierzeń budowlanych, to jeden z ważniejszy postulatów, jaki należy wcielić w życie, aby zmienić dynamikę gospodarczą regionów i miast, a zarazem stworzyć lepsze warunki dla rozwoju biznesu.

\section{PODSUMOWANIE}

Przedstawione przykłady dobrych praktyk nakreślają kompetencje i zakres współpracy środowiska architektów z samorządami i po części uczelniami wyższymi. Sprawnie działające mechanizmy, pozwalające inwestować kapitał w jakość architektury i urbanistyki, niewątpliwie przynosi o wiele więcej wymiernych korzyści wszystkim zainteresowanym stronom. W najbliższym czasie pojawi się wiele zmian w prawie dotyczących zarówno projektowania, jak i realizacji zamierzeń budowlanych. Miejmy nadzieję, że nie przyniesie to zastoju, ale wręcz przeciwnie - zwiększy dynamikę sektora budowlanego.

\section{PRZYPISY}

1 http://www.sarp.org.pl/ (dostęp: 10.08.2017).

2 http://www.sarp.krakow.pl/ (dostęp: 10.08.2017).

3 M. Mostafa, Sprawozdanie Zarzqdu Oddziału Warszawskiego SARP za lata 2012-2015, Warszawa 2015, s. 4. 
4 Konkurs jako instrument kreowania ładu przestrzennego, wysokiej jakości budynków i przestrzeni publicznych, Stelmach B., Konior T. (red.), Materiały z Forum Konkursów Architektonicznych, 27-28 czerwca 2014, Warszawa, s. 4.

5 Ibidem, s. 15.

6 http://mba2017.sarp.krakow.pl (dostęp: 10.08.2017).

7 http://www.sarp.krakow.pl/attachments/811l_58763fac03927_Regulamin_Dyplom_Roku_ edycja_2017_11.01.16.pdf (dostęp: 10.08.2017).

8 Dom dla rodziny: Krynica-Zdrój, 21-22 października 2016 r., Rada i biuro MPOIA, Izba Architektów Rzeczypospolitej Polskiej, Małopolska Okręgowa Izba Architektów RP.

\section{BIBLIOGRAFIA}

Dom dla rodziny: Krynica-Zdrój, 21-22 października 2016 r., Rada i biuro MPOIA, Izba Architektów Rzeczypospolitej Polskiej, Małopolska Okręgowa Izba Architektów RP.

Konkurs jako instrument kreowania ładu przestrzennego, wysokiej jakości budynków i przestrzeni publicznych, Stelmach B., Konior T. (red.), Materiały z Forum Konkursów Architektonicznych, 27-28 czerwca 2014, Warszawa.

Mostafa M., Sprawozdanie Zarzq̨du Oddziału Warszawskiego SARP za lata 2012-2015, Warszawa 2015.

http://www.mpoia.pl/ (dostęp: 10.08.2017).

http://www.sarp.org.pl/ (dostęp: 10.08.2017).

http://www.sarp.krakow.pl/ (dostęp: 10.08.2017).

http://www.sarp.krakow.pl/attachments/811l_58763fac03927_Regulamin_Dyplom_Roku_ edycja_2017_11.01.16.pdf (dostęp: 10.08.2017).

http://mba2017.sarp.krakow.pl/ (dostęp: 10.08.2017). 